\title{
グローバル化と精梁工学
}

\section{国際標準戦略にかかわる政策的取り組み* \\ Policy Action for Strategic International Standardization}

\section{田村 傑** 松田宏雄 ${ }^{* * *}$ \\ Suguru TAMURA and Hiroo MATSUDA}

\section{1. 世界の情 勢}

経済成長戦略大綱「科学技術によるイノベーションを生 み出す仕組みの強化」をはじめとして, 第 3 期科学技術基 本計画あるいは知的財産戦略本部「国際標準総合戦略」な どにおいて, 我が国の産業競争力強化の施策に国際標準化 が果たす大きな役割が掲げられている.

この背景には, グローバル化した産業社会の変化があ る. 物資の流通が国内を中心とする地域産業から, 大量な 物質・機材の輸出入を伴う貿易産業へ変化し，特に 1995 年にWTO/TBT 協定（世界貿易機関/貿易における技術 的障害に関する協定）が発効して以来, 世界各国の工業標 準化戦略は, 表 1 の ISO/IEC/ITU（国際標準化機構/国 際電気標準会議/国際電気通信連合）などのデジュール世 界標準を制定することが共通認識となっている，WTO/ TBT 協定とは, 規格の立案・適用やその適合性評価活動 が不当に行われ，それらが貿易規制につながることがない ように加盟国を規律するもので, ISO/IEC 等の国際規格 を各国内技術規制の基礎とするように義務づけたものであ る．特に，2001 年に中国がWTOに加盟したことが，今 後大きな成長が期待される中国市場への進出を図る欧米各 国にとって，国際標準を視野に入れた活動を活発化させる こととなった.

米国は自国内の市場が大きく, さらに先進産業技術が国 内規格化されてそのまま世界標準として通用する基盤が確 立していたため, 90 年代前半までは国際標準の獲得に熱

*原稿受付 平成 19 年 11 月 8 日

“経済産業省産業技術環境局基準認証ユニット標準企画室補佐（東京都千代 田区霞が関 1-3-1） 03-3501-9245

**** (独) 産業技術総合研究所産学官連携推進部門工業標準部長(茨城県つくば 市梅園 1-1-1 第 2 事業所)

田村 傑

経済産業省産業技術環境局基準認証ユニット標準企画室補佐

松田宏雄

1981 年早稲田大学大学院理工学研究科応用化学専攻博士前期課程修了. 1989 年工学博士 (早稲田大学). 専門分野は有機光電子機能材料. 2005 年 より現職。
心ではなかったが, WTO/TBT 協定の発効以来, ISO/ IECでの活動を急速に活性化させている。欧州はもともと 多国の集合体であり，欧州域内での規格共通化が不可欠で あるところから，国際標準の獲得にも力を入れてきた。欧 州域内の地域標準機関である CEN/CENELEC で制定され た欧州標準は, 専門家の議論無しに ISO/IEC 国際規格案 として投票にかけることができる特権を有している.

これらの世界各国の国際標準化への取り組み強化は, 標 準の対象が製品にとどまらず，環境への配慮や組織構造の 標準化といった新たな分野にも拡大しつつあり, これに適 時・適確に対応することが, 新たなビジネスチャンスにお いて国際競争力を発揮するために必須となっている。国際 標準の制定プロセスを図 1 に示すが, 各国の利害関係者 調整に時間をかけた丁寧な対応が求められ, 特に, 会議に おけるコンセンサス形成には信頼される人間関係構築と政 策的な支援が不可欠であることから，官民を挙げて長期 的・戦略的な対応が求められることは言うまでもない.

\section{2. 我が国の対応}

こういった背景のもと, 前章の冒頭に示したいくつかの 戦略施策がまとめられたが，特に，「科学技術によるイノ ベーションを生み出す仕組みの強化」では, 研究から市場 へ，市場から研究へ双方向の連携を軸としたイノベーショ ンハイウエイ構想が打ち出され，イノベーションを加速す る環境整備の中で国際標準化が推進されることとなった。 加えて経済産業省においては, 平成 18 年 11 月 29 日「国 際標準化官民戦略会議」を開催, 官民の強力な連携の下で 「国際標準化戦略目標」を達成することに合意した。そこ では，2015 年までに欧米諸国に比肩しうるよう，国際標 準化を戦略的に推進する戦略目標として, 国際標準提案件 数の倍増と欧米各国並の幹事国引き受けが掲げられてい る。具体的にそれらにおける我が国の実績は表 2, 表 3 の ように整理され, 前者は全体の $10 \%$ 程度, 後者は先進各 国の半分程度にとどまっている。図 2 にSOにおける幹 事国数の推移を示す。我が国は着実に幹事国引き受け数を 増大させてきているが, さらに積極的に取り組んでいく予 
表 1 国際標準化機関

\begin{tabular}{|c|c|c|c|c|}
\hline & \multirow{2}{*}{$\begin{array}{c}\text { 国際標準化機構 } \\
\text { ISO } \\
\text { International } \\
\text { Organization for } \\
\text { Standardization }\end{array}$} & \multirow{2}{*}{$\begin{array}{c}\text { 国際電気標準会議 } \\
\text { IEC } \\
\text { International } \\
\text { Electrotechnical } \\
\text { Commission for } \\
\text { Standardization }\end{array}$} & \multicolumn{2}{|c|}{$\begin{array}{c}\text { 国際電気通信連合 } \\
\text { ITU } \\
\text { International } \\
\text { Telecommunication Union }\end{array}$} \\
\hline & & & $\begin{array}{c}\text { 無線通信部門 } \\
\text { ITU-R } \\
\end{array}$ & $\begin{array}{c}\text { 電気通信標準化部門 } \\
\text { ITU-T } \\
\end{array}$ \\
\hline 分野 & 電気，通信分野を除く全分野 & 電気技術分野 & 無線通信技術分野 & 有線通信技術分野 \\
\hline 規格数 & 16455 規格 & 5454 規格 & 約 1250 規格 & 約 3000 規格 \\
\hline 設立年 & $\begin{array}{l}1926 \text { 年：ISA 設立 } \\
1947 \text { 年：ISO へ改組 }\end{array}$ & 1906 年 & \multicolumn{2}{|c|}{$\begin{array}{l}1865 \text { 年 : 万国電信連合設立 } \\
1932 \text { 年 : ITU へ改組 }\end{array}$} \\
\hline 会員数 & $\begin{array}{rr}\text { 正会員 } & 104 \\
\text { 準会員 } & 51 \\
\text { 計 } & 155\end{array}$ & $\begin{aligned} \text { 正会員 } & 51 \\
\text { 準会員 } & 14 \\
\text { 計 } & 65\end{aligned}$ & $\begin{array}{l}\text { 加盟国 } \\
\text { 企業会員 }\end{array}$ & $\begin{array}{l}191 \\
650 \text { 以上 }\end{array}$ \\
\hline
\end{tabular}

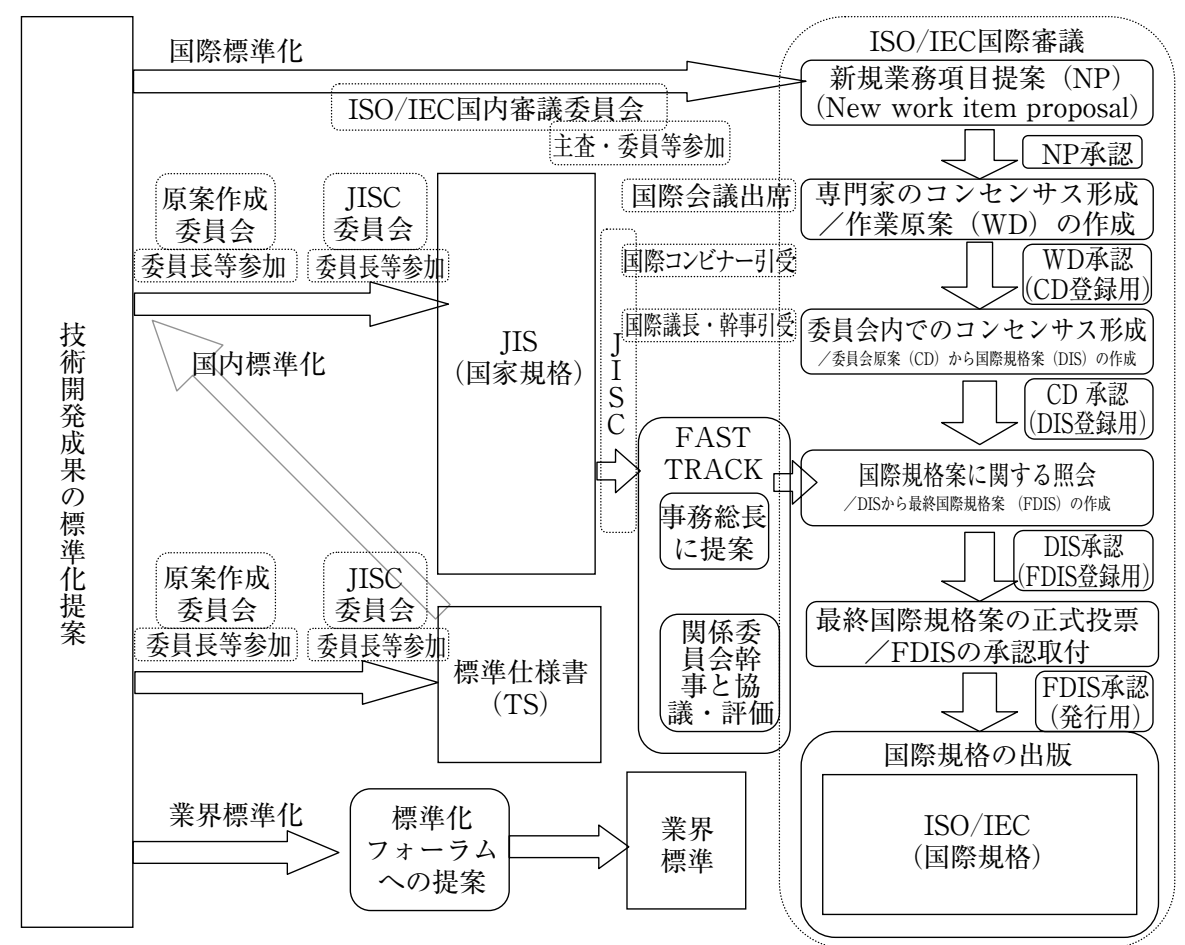

図1 国際標準制定プロセス

定である。ささらに，具体的な実行プランとして，平成 19 年 7 月に国際標準化アクションプランの改訂を行ってい る。 そこでは次の 5 項目にわたって, 産業界, 学界, 政策 当局に期待する指針が示されている.

(1) 企業経営者の意識改革

(2) 国際標準の提案に向けた重点的な支援強化

(3) 世界で通用する標準専門家の育成

(4) アジア太平洋地域に扔ける連携強化

(5) 諸外国の独自標準と技術規制制定への対応 これらの中で, 研究開発機関に扔ける標準化推進では, 我 が国が優位にある技術分野において研究開発と標準化の一 体的推進を図ること，技術専門家として標準化審議をリー ドできる人材の輩出が求められている。経済産業省では, 国際標準の原案作成に関わっている人，または，今後関わ
る予定の人を対象に，ISO や IEC における規格作成の基 本的事項や規格構成, 規格案作成の実習研修, ならびに ISO や IEC において日本代表として活動する人，または その可能性のある人を対象に, 国際会議の運営方法・慣 習, 経験豊かな経験者によるケーススタデイ, ロールプレ イについての研修を実施している。

くわえて, 標準分野で活躍する人材の裾野を中長期的に 広げるべく, 大学（学部・大学院）および企業で利用しゃ すい標準に関するモデル教材を開発・提供し, 教育機関や 企業における自主的な取り組みを促している。また，関西 学院大学（MBA）に扔いて，平成 19 年 6 月〜 7 月に寄付 講座（「ビジネスソリューションとしての標準化」）拈よび 千葉大学に拈いて, 平成 19 年 7 月 9 月に電気・電子. 情報分野に関する公開講座を実施し, 東京工業大学 


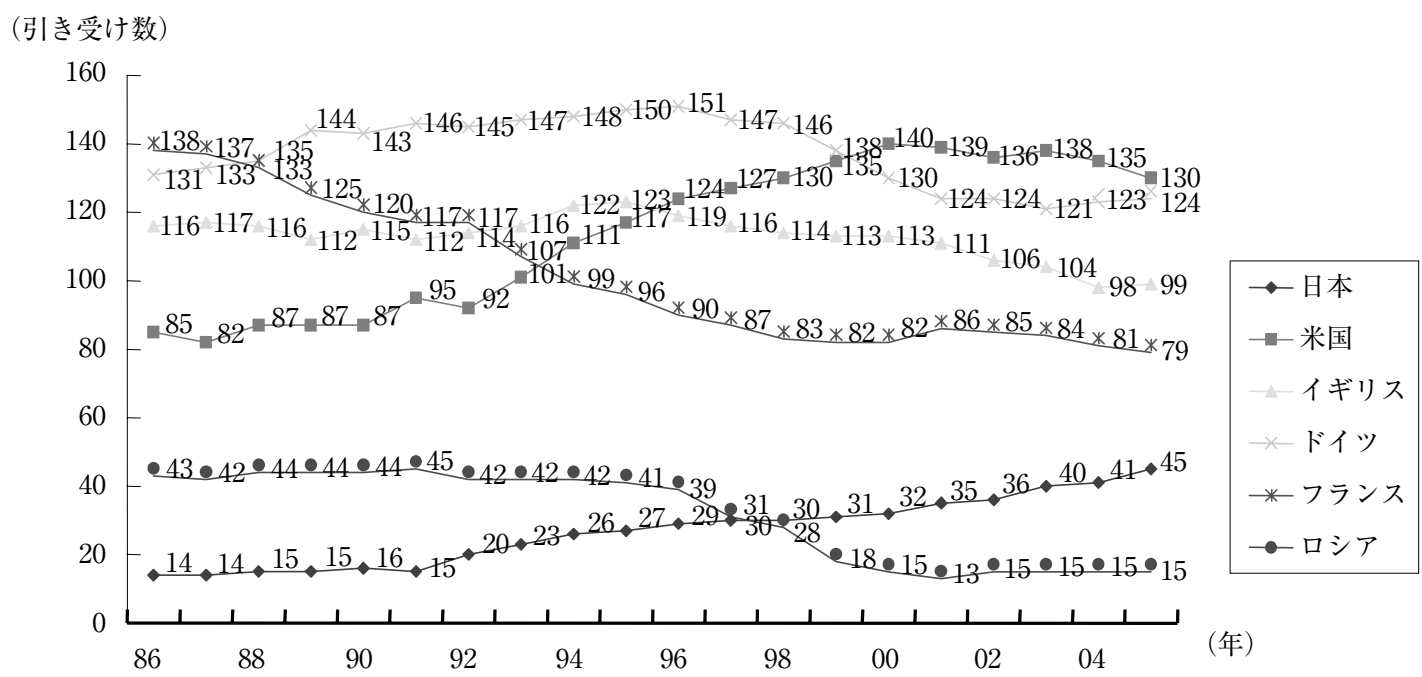

（備考） 88 年以降の引き受け数には, IEC との合同委員会（JTC1）の幹事も含む.

(出典) ISO「MEMENTO」

図 2 ISO 幹事国業務（TC/SC）引き受け数の推移

表 2 国際標準化機関への年間提案件数

2001 年〜2003 年の平均

\begin{tabular}{c|c|c|c|c|c}
\hline \multicolumn{3}{|c|}{ ISO } & \multicolumn{3}{c}{ IEC } \\
\hline 総数 & 日本 & 割合 & 総数 & 日本 & 割合 \\
\hline 619 & 44 & $7.2 \%$ & 96 & 19 & $19.1 \%$ \\
\hline
\end{tabular}

表 3 国際標準化機関技術専門委員会幹事国引受数

2006 年 2 月現在

\begin{tabular}{c|r|r|r|r|r|r}
\hline & \multicolumn{1}{|c|}{ 独 } & \multicolumn{1}{|c|}{ 米 } & 英 & 仏 & 日 & 中 \\
\hline ISO & 126 & 123 & 100 & 77 & 47 & 9 \\
\hline IEC & 25 & 25 & 25 & 25 & 13 & 3 \\
\hline 合計 & 151 & 148 & 125 & 102 & 60 & 12 \\
\hline
\end{tabular}

（MOT）において, 平成 19 年 10 月〜平成 20 年 1 月（「イ ノベーションと標準化」）に寄付講座を開講している*1.

\section{3. 研究開発と標準化の一体的推進}

研究開発と標準化の一体的推進の必要性と効果は, 図 3 に概略的に示したように，研究プランニングの段階から標 準化を視野に入れた計画を遂行することによって，技術展 開の方向性をあらかじめ予測しながらそろえ, あるいは標 準化に必要な技術デー夕を研究開発と同時に集積すること によって，標準獲得に必要な期間を大幅に短縮でき，その 結果として戦略的な市場獲得が可能になるというものであ る。もちろん，標準化議論の仕組みに関する専門的知識は 必要であるが，標準化対象技術の専門家が標準策定議論に 積極的に参加して議論をリードすることは，研究者ネット ワークを活用したコンセンサス形成の利点もあり，大いに 有意義である，実際に国際標準化に携わっている研究者か らは，次のような効用が指摘されている。

*1 経済産業省では, 大学・大学院・研究機関に扔ける標準化教育・研修 の支援を積極的に行っております，教材の供与，講師の派遣など御関心 ある場合には御連絡ください

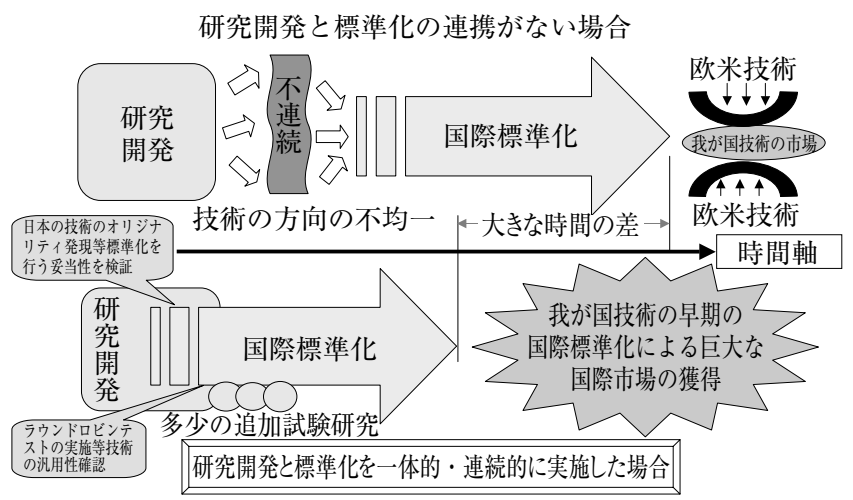

図 3 研究開発と標準化の一体的推進

・規格文書は, 研究論文よりも当該分野の産業界への インパクトが大きい.

・国際標準議論においてバックデータとしての論文化 が重要であり，論文が活用できる.

・標準案作成のための委員会では，学会発表とは異な る視点の議論ができ，さらに，国際的な視点も加え た研究展開に役立つ。

・海外組織との関係において, 単なる開発競争ではな い国際協調関係を築くことができた.

・標準化議論を通じて産業界のニーズを取り入れ，研 究目標を適時修正することによって，より実用的な 成果に近づくことができた。

先にも述べたように，標準化議論には長期的な取り組みが 必要であり，第一線の研究者が自ら取り組むためには，そ の活動を積極的に評価し，研究資金の上からも支援体制を 確立しておかなければならない。同様に，研究開発におい て標準化活動が重要である理由は, 計測方法や評価方法の 標準化により基礎的研究成果の製品化が進展し，学術的な 研究成果の価值が高まるとの側面もある。これは，科学技 術の成果は，実生活に対する影響が高まれば高まるほど， 


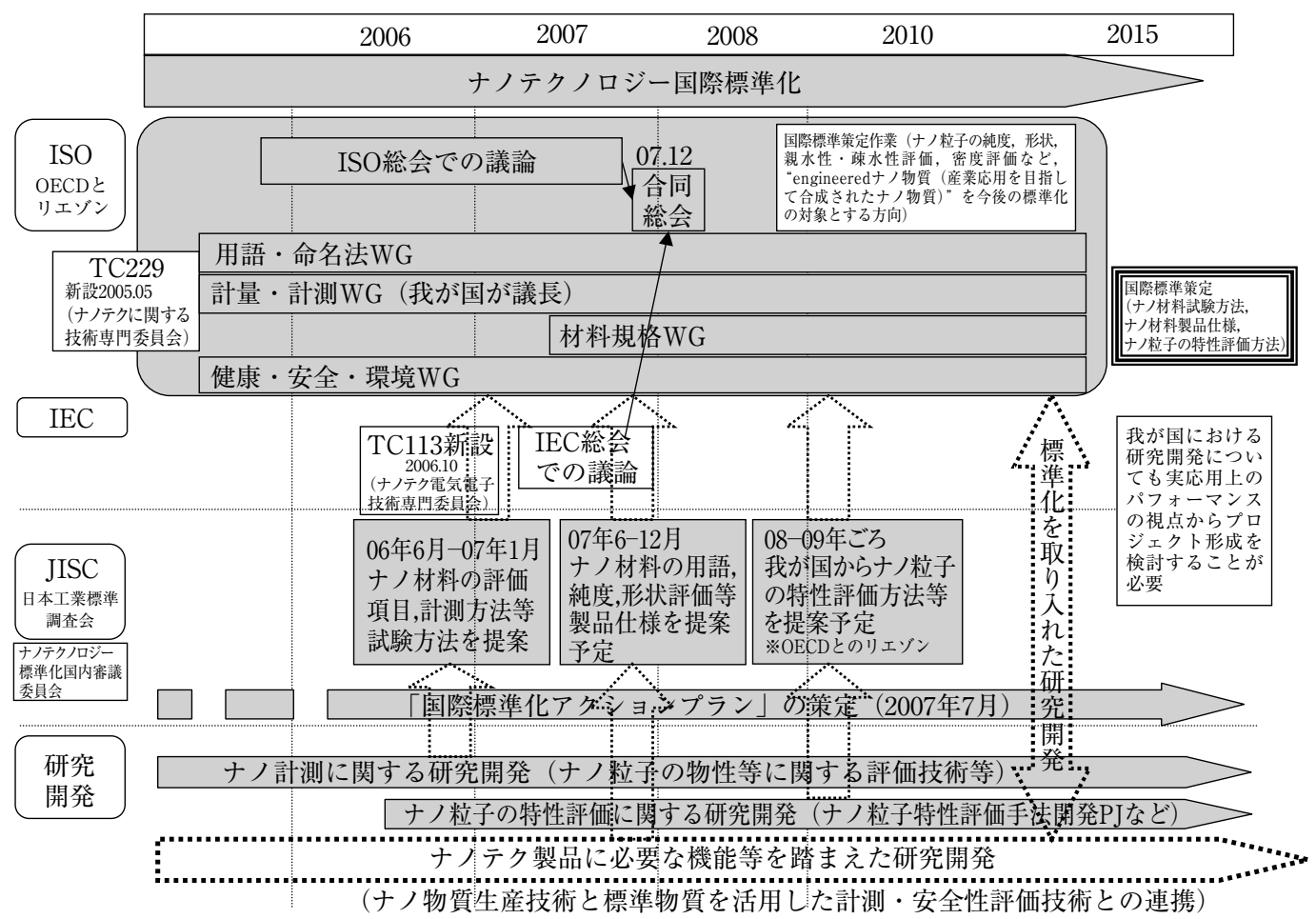

図 4 ナノテクノロジー分野における標準化シナリオ

高く評価される循環となるからである，例えば，光触媒の 例では，光触媒の評価方法などの標準化が進展したことに より，製品が日常生活に必要不可欠なほど普及した結果， 関連する研究を誘発して学術的な研究成果の評価が自律的 に高まるとの好循環を生み出している。これからの国家的 研究開発プロジェクトには，必ず標準化の視点を組み込ん でいくことが政策的に推奨されることになるであろう.

研究開発と国際標準化が一体的に推進されている具体的 な事例として，ナノテクノロジー国際標準化が挙げられ る. 日本発の多くの新技術があるナノテクノロジーが次世 代産業の中核となることが大いに期待され，我が国が国際 的な競争力と発言力を確保して, 現在の比較優位な立場を 堅持しなければならないという認識は，産学官で共通して いる．同時に，実社会にナノテクノロジー材料を含む製品 が大量に出回る前に, そのような新技術に対する安全評価 基準が議論されることが大切であるとの立場から，まず議 論の基盤となる標準を確立するために, ISO/TC229（ナ ノテクノロジー）が 2005 年 5 月に設立された。これらの 動向に対して, 国内では経済産業省（日本工業標準調査会 JISC）を中心とする体制整備が進められたが, 将来の産 業分野でありかつ既存の多様な産業に広くまたがる技術分 野であるところから，特定の企業団体あるいはある一つの 学会では国際標準化活動に十分な体制を取ることができな
かった。 そこで, 当該分野の材料, 計測, 安全性評価に関 する研究で幅広い知見と人材を有する(独) 産業技術総合研 究所が, ISO/TC229に対応する国内審議団体としての役 割を果たすことになり，(独)新エネルギー産業技術基総合 開発機構（NEDO）からの調査委託事業に基づいて，国内 審議体制を確立した。 TC229 第 1 回総会（ロンドン）で WG2（計測・キャラクタリゼーション）のコンベナーを 獲得することができ, ナノテクノロジーの計測分野で, 国 際標準化議論をリードしている．2007 年 3 月には，IEC/ TC113（ナノテクノロジー）も設立され，我が国は両者の 協調を図って国際標準化審議を進める体制が構築されてい る。最後に経済産業省がまとめているナノテクノロジー分 野における標準化シナリオを図 4 に示し, 関係各位の標 準化推進に期待する.

\section{参 考 文 献}

1) 国際標準総合戦略（内閣官房知的財産戦略本部 2006 年 12 月 6 日)

http://www.kantei.go.jp/jp/singi/titeki2/tyousakai/cycle/dai8/ 8siryoul.pdf

2）国際標準化戦略目標（経済産業省 2006 年 11 月 29 日） http://www.jisc.go.jp/policy/senryakumokuhyo.html

3）国際標準化アクションプラン（日本工業標準調査会 2007 年 7 月)

http://www.jisc.go.jp/policy/actionplan2007.html 